(RESEARCH ARTICLE)

\title{
Evaluation of DSSAT model to predict sorghum yields under Conservation Agriculture in the Pandamatenga vertisols of Northern Botswana
}

\author{
Kapweke Kandondi ${ }^{1}$, Mpuisang Thembeka ${ }^{1}$, Benedict Kayombo $1{ }^{*}$ and Davis Samzala Marumo ${ }^{2}$ \\ ${ }^{1}$ Department of Agricultural and Biosystems Engineering, Botswana University of Agriculture and Natural Resources, \\ Private Bag 0027, Gaborone, Botswana. \\ ${ }^{2}$ Department of Agricultural and Applied Economics, Botswana University of Agriculture and Natural Resources, Private \\ Bag 0027, Gaborone, Botswana.
}

Publication history: Received on 14 October 2020; revised on 23 October 2020; accepted on 27 October 2020

Article DOI: https://doi.org/10.30574/wjaets.2020.1.1.0014

\begin{abstract}
This study was conducted at Pandamatenga of Chobe District in northern Botswana. The main aim of the study was to evaluate the Decision Support System for Agrotechnology Transfer (DSSAT) model in the prediction of sorghum yields under Conservation Agriculture (CA) technologies. A field experiment was conducted at the Pandamatenga Agricultural Research station during the 2015-2017 growing seasons. A randomized complete block design was used for the onstation field experimentation. The design had trial plots with four treatments, namely No Tillage (NT), No Tillage + Mulch (NT+M), Minimum Tillage (MT), and Broad Bed and Furrow (BBF), with four replicates rotated between sorghum cowpea. Sorghum grain yield results were analyzed using the Statistical Analysis Software (SAS version 9.2). Analysis of variance and means were separated using Duncan's multiple range test at 5\% confidence level. The DSSAT model was evaluated using the experimental data and weather data for the growing periods. The model was further used to test these CA technologies in terms of sorghum grain yield in the future. The DSSAT crop model provided reasonable predictions of sorghum grain yield under NT, MT, NT+M, and BBF on vertisols of Pandamatenga. The model furthermore predicted that sustained NT+M practice by smallholder rainfed farmers in Pandamatenga would increase sorghum grain yield production in the future.
\end{abstract}

Keywords: Conservation Agriculture technologies; sorghum grain yields; DSSAT model; mid-century sorghum yields

\section{Introduction}

Conservation Agriculture is an important alternative farming system in the control and improvement of the soil regimes in vertisols for increased crop production thus improving livelihoods [1]. Furthermore, no tillage is a suitable management option for clay soils as it minimizes sub-soil compaction and induces natural structure formation through shrink-swell cycles [2]. The maintenance of a permanent soil cover with mulch or cover crops also increases the stability of vertisols [3]. Residues provide a constant food source for the soil fauna and flora and a habitation of many organisms. These organisms produce soil pores and their increased biological activity with crop residue retention enables the slow breakdown of the residues and incorporate these residues in the soil as organic matter [4]. Soil organic matter promotes aggregation through the linkage of clay-organic matter [5]. The effectiveness of CA to address the above-mentioned problems, however, largely depends on the capacity of change agents and farmers in applying the actual formulae and techniques of the principles of CA to local context [6]. Short term to medium term potential benefits of CA have been assessed on farms. Conservation Agriculture generally results in increased yields especially after 3-5 years largely due to improved rainfall infiltration, reduction in number of labour hours and increased returns reduction in risk of economic returns. Long term studies that report the long-term effects of CA on crop productivity and net economic

\footnotetext{
${ }^{*}$ Corresponding author: Benedict Kayombo

Department of Agricultural and Biosystems Engineering, Botswana University of Agriculture and Natural Resources, Private Bag 0027, Gaborone, Botswana.
} 
returns including risks are, however, lacking in Botswana and Southern Africa as a whole. At the same time, traditional experiments aimed at deriving appropriate cropping practices for the wide variety of soil types and climatic conditions are time consuming and expensive [6].

The use of crop simulation models (CSMs) is often considered useful tool to simulate different soil and crop management and climatic scenarios for developing the most suitable and site-specific strategies [7]. The DSSAT is a collection of several such models, which connects the decision support system to crop simulation models [7]. The DSSAT model can simulate the influence of CA practices on soil properties and plant growth to guide the choice of the most efficient management options. The DSSAT model has been calibrated and evaluated in Malawi to model CA in maize yield in respond to climate change [6]. The use of models to simulate combinations of tillage systems and crop rotations constitute a powerful tool in assisting decision making to identify efficient system management options, increasing yields and decreasing environmental impacts, in specific-climatic conditions [8]. Msongaleli et al. [9] used the DSSAT model to evaluate and simulate sorghum yield under current and future climate. The results showed the crop simulation models' applicability as tools for assessing impacts of climate change on sorghum yields. The use of crop models to simulate the effects of CA technologies on crop development and the ability of DSSAT model to predict crop yields in the mid - century have not been assessed in Botswana. The objectives of this study were therefore to evaluate the DSSAT model in the prediction of yields of sorghum under CA and predict the yield during the mid - century.

\section{Material and methods}

\subsection{Description of the study area}

The study was based at Pandamatenga Agricultural Research station. Pandamatenga lies in the northern part of Botswana between latitude 18 $32^{\prime}$ South, and longitude 25 $38^{\prime}$ East and covers an area of 280,380ha (Figure 1). The Pandamatenga farms (Figure 2) cover only 25,074 ha of this total land area [10].

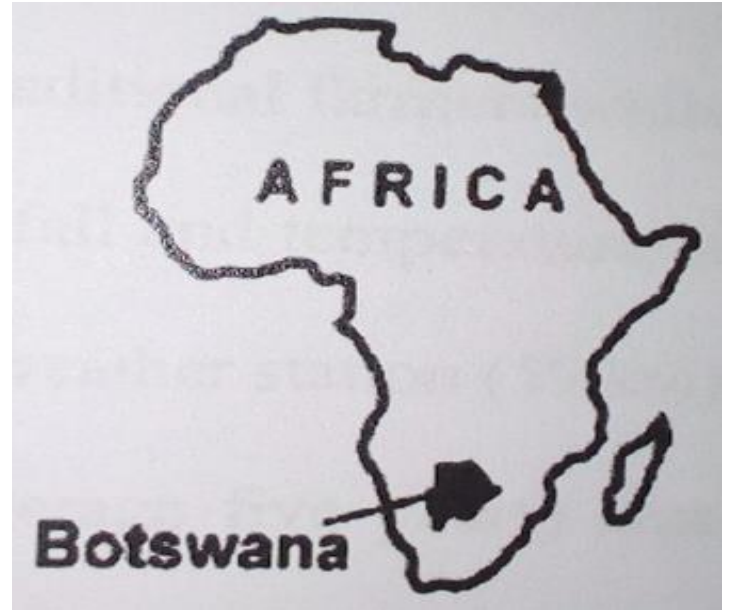

Figure 1 Location of study area in Africa

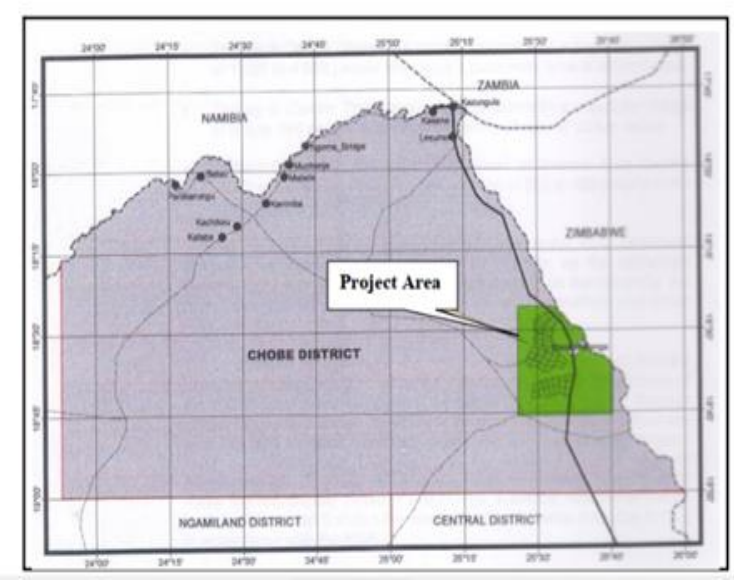

Figure 2 Detailed inset of Pandamatenga Farms

The climate for the Pandamatenga region is semiarid characterized by hot and moist summers and dry mild winters. Rainfall is derived from convective processes and is highly variable even over small distances and averages $600 \mathrm{~mm}$ annually. Almost all rain falls between October and April, with December, January and February being the peak months. A substantial proportion of this rain falls in short duration of high intensity storms, thus, leading to high run-on into some farms, which become flooded instantly. Maximum temperatures range between $26^{\circ} \mathrm{C}$ to $34^{\circ} \mathrm{C}$ and are experienced between October and March. Minimum temperatures range between $11^{\circ} \mathrm{C}$ to $20^{\circ} \mathrm{C}$ and are experienced between November and July. The vegetation is extensive grassland savannah in association with mopane (Colophospermum mopane) and acacia species [11].

\subsection{Experimental design}

The field experiment was conducted at the Pandamatenga Agricultural Research station under rainfed conditions during 2015/17 growing seasons. A randomized complete block design was used for the field experimentation with plot dimensions of $20 \mathrm{~m} * 7.5 \mathrm{~m}$. The design was subjected to the on-station trial plots with four treatments, namely No Tillage (NT), No Tillage + Mulch (NT+M), Minimum Tillage (MT) and Broad Bed and Furrow (BBF), with four replicates rotated 
between sorghum and cowpea. Sorghum variety Segaolane and cowpea variety Tswana were used for the experiment. The planting dates were on the month of February in 2015 and 2016 while in 2017 the planting date was on the month of March. A field book was used to record all relevant variables (sorghum grain yield, anthesis date and days to maturity) for three consecutive cropping seasons between the years 2015 and 2017.

\subsection{The DSSAT Model}

The DSSAT 4.6 model was used in this study. The model simulated crop growth, development and yield using specific data on crop management, minimum weather data and soil profile parameters. The DSSAT model required the following crop data for simulation: crop name, cultivar, plant density and harvested grain yield. The weather data for Pandamatenga Agricultural Research station was used. The required minimum weather data for the DSSAT model included daily solar radiation $\left(\mathrm{MJ} / \mathrm{m}^{2}\right)$, daily maximum and minimum air temperature $\left({ }^{\circ} \mathrm{C}\right)$ received by the crop canopy and daily precipitation (mm). The daily weather data for this study (2015-2017) was obtained from the Department of Metrological Services in Gaborone. The data was formatted and input into DSSAT using the Weatherman software. The soil profile input included wilting point water content, field capacity, saturated water content, $\left(\mathrm{cm} / \mathrm{cm}^{3}\right)$, bulk density $\left(\mathrm{g} / \mathrm{cm}^{3}\right)$, soil organic matter content (\%), saturated hydraulic conductivity (m/day), soil pH, clay and silt particle size (\%). The soil data for the same experimental site was obtained from the DSSAT soil database. The above data were used to construct the model soil profile (Table 1).

Table 1 Physical and Chemical Properties of Pandamatenga vertisol

\begin{tabular}{lllllllll}
\hline $\begin{array}{l}\text { Depth } \\
(\mathrm{cm})\end{array}$ & $\begin{array}{l}\text { Bulk } \\
\text { density } \\
\left(\mathrm{g} / \mathrm{cm}^{3}\right)\end{array}$ & $\begin{array}{c}\mathrm{UL} \\
\left(\mathrm{cm}^{3} \mathrm{~cm}^{-3}\right)\end{array}$ & $\begin{array}{c}\mathrm{LL} \\
\left(\mathrm{cm}^{3} \mathrm{~cm}^{-3}\right)\end{array}$ & $\begin{array}{l}\text { Sat. water } \\
\text { content } \\
\left(\mathrm{cm}^{3} \mathrm{~cm}^{-3}\right)\end{array}$ & $\begin{array}{l}\text { Organic } \\
\text { carbon } \\
(\%)\end{array}$ & $\begin{array}{l}\text { Clay } \\
(\%)\end{array}$ & $\begin{array}{l}\text { Silt } \\
(\%)\end{array}$ & \begin{tabular}{c}
$\mathrm{pH}$ \\
\hline $0-5$
\end{tabular} \\
\hline 1.32 & 0.388 & 0.236 & 0.515 & 0.90 & 61 & 10 & 7.04 \\
$5-15$ & 1.33 & 0.388 & 0.236 & 0.518 & 0.90 & 64 & 11 & 7.10 \\
$15-25$ & 1.32 & 0.377 & 0.236 & 0.518 & 0.80 & 68 & 10 & 7.10 \\
$25-40$ & 1.34 & 0.380 & 0.235 & 0.514 & 0.80 & 71 & 9 & 6.50 \\
$40-55$ & 1.33 & 0.379 & 0.236 & 0.523 & 0.70 & 73 & 8 & 6.50 \\
$55-70$ & 1.33 & 0.388 & 2.236 & 0.515 & 0.70 & 73 & 9 & 6.50 \\
$70-100$ & 1.32 & 0.377 & 0.236 & 0.514 & 0.80 & 74 & 8 & 7.50 \\
&
\end{tabular}

\subsubsection{Statistical evaluation of the model}

Calibrated sorghum genetic coefficients from another previous study were used, and so the model was not calibrated. To evaluate model performance, simulated and measured crop yields and anthesis dates were compared by changing the soil data initial conditions in the model and analyzed by using the following statistics: The Root Mean Square Error (RMSE), Mean Error (E), Modelling Efficiency (EF), index of agreement (d), and linear regression with the coefficient of determination $\mathrm{R}^{2}[12,13]$. A paired $\mathrm{t}$ - test was used to detect whether the mean error, E, was significantly different from zero [14]. Statistical evaluation was conducted using EasyGrapher 12 v4.6 software [13]. The above statistics were calculated as follows:

$\operatorname{RMSE}=\sqrt{\sum_{i=1}^{n}\left(S_{i}-M_{i}\right)^{2} / n}$

RMSE is a measure of accuracy to compare the simulated and observed data. The value of RMSE equal to zero indicates the goodness of fit between predicted and observed data.

Mean Error, $\mathrm{E}=\frac{1}{n} \sum_{i=1}^{n}\left(S_{i}-M_{i}\right)$

E determines if model predictions tend to underestimate (negative) or overestimate (positive) the measurements.

$\mathrm{EF}=1-\frac{\sum\left(S_{i}-M_{i}\right)^{2}}{\sum\left(S_{i}-\bar{S}\right)^{2}}$ 
$\mathrm{EF}$ is a relative measure of error, $\mathrm{EF}=1$ correspond to a perfect match of modelled output with the observed data, $\mathrm{EF}=$ 0 indicate that the model predictions are as accurate as the mean of the observed data, whereas an efficiency of less than zero occurs when the observed mean is a better predictor than the model.

$\mathrm{d}=1-\frac{\sum_{i=1}^{n}\left(S_{i}-M_{i}\right)^{2}}{\sum_{i=1}^{n}\left(\left|S_{i}^{\prime}\right|+\left|M_{i}^{\prime}\right|\right)^{2}}$

The $\mathrm{d}$ statistic $(0 \leq \mathrm{d} \leq 1)$ is used primarily to determine the relative "degree of agreement" (or alternatively, relative "degree of error" between simulated and measured values, with $d=0.0$ indicating no agreement (i.e. complete randomness) and $\mathrm{d}=1.0$ indicating perfect agreement or 15 . zero error.

Where $S_{i}$ and $M_{i}$ are the ith simulated and measured data, respectively, $\mathrm{n}$ is the number of values, $S_{i}^{\prime}=S_{i}-\bar{M}$ and $M_{i}^{\prime}=$ $M_{i}-\bar{M}, \bar{M}$ is the average of the measured values.

\subsection{Prediction of sorghum grain yield under CA using mid-century weather data (2040 -2070)}

Results showed that simulated values of the model matched well with the observed values of sorghum grain yield from the experimental site. Therefore, this model was used to predict sorghum grain yield using mid - century weather data. The methodology of developing the future weather was obtained from the Agricultural Model Intercomparison and Improvement Project (AgMIP) under the Representative Concentration Pathways (RCP) 4.5 and 8.5 climate scenario for Pandamatenga area [15]. The Representative Concentration Pathway 4.5 refers to the intermediate emissions which consist of lower energy intensity, strong deforestation programmes and decreasing use of croplands and grasslands due to increased yield whilst RCP 8.5 consists of high emissions with a future of no policy changes to reduce emissions [16]. The future weather data were used to create the weather data file in the DSSAT model for yield prediction in the future. The RCP 4.5 hot and dry weather data were extracted from the Canadian Earth System Model, the second generation (CanESM2). The hot and wet (RCP 4.5) weather data were extracted from Hadley Centre Global Environment Model, version 2 Earth Systems (HadGEM2-12. ES). Furthermore, the RCP 8.5 hot and dry weather data were generated from Max Planck Institute Earth System Model at Lower Resolution (MPI-ESM-LR). The soil and crop management conditions were kept the same as in the 2015 - 2017 seasons.

\section{Results and discussion}

\subsection{Weather data for Pandamatenga Department of Agricultural Research Station}

The weather data for the study area is shown in Figure 3. The month of February had the highest amount of rainfall in all the growing seasons. The highest temperatures were experienced in January and October.

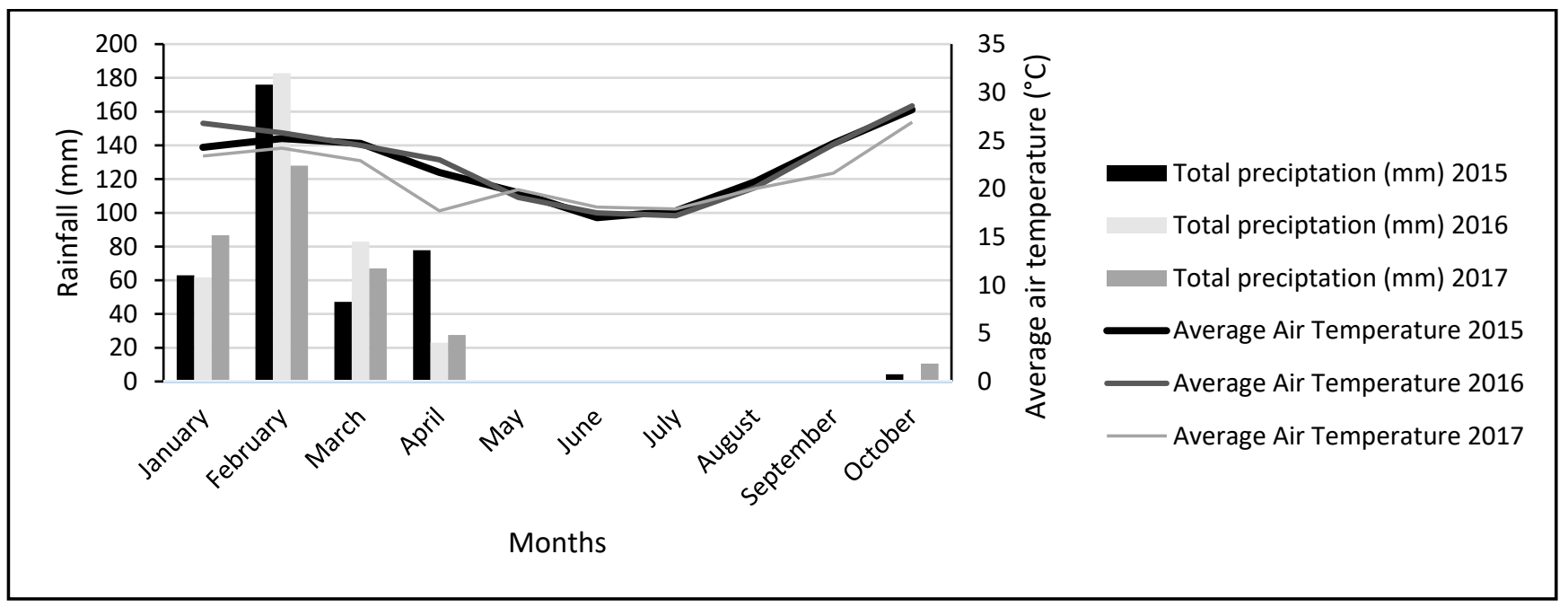

Figure 3 Average air temperature $\left({ }^{\circ} \mathrm{C}\right)$ and total rainfall amount $(\mathrm{mm})$ for the growing seasons (2015 to 2017) 


\subsection{Evaluation of the DSSAT model}

In this study the DSSAT model was used to model sorghum grain yield under CA technologies. The evaluation of the model was performed using the field experiment for 2016 growing season. The variables that were used for evaluation were anthesis date, maturity date and sorghum grain yield. The mean value of days after planting simulated for anthesis (56 days) was slightly higher compared to the mean of observed values ( 54 days). The evaluation process revealed that the model predicted days to flowering and days to maturity for sorghum grain yield very well as the RMSE value was low (Table 4). This index indicates that the model works well in simulating the anthesis and days to maturity, which are important phases for sorghum growth. The E at (0) for days to maturity and 0.5 anthesis days were relatively low indicating that there was no overestimate or underestimate of the model to the data. The coefficient of determination $\mathrm{R}^{2}$ indicated that 90\% (anthesis) and 99\% (days to maturity) of the total variation was explained by the model. Values of the modelling efficiency index $(\mathrm{EF}=0)$ indicated that the model predictions were as accurate as the mean of the observed data, although the index of agreement showed poor model data agreement (Table 4). The mean value of simulated sorghum grain yield $(1137 \mathrm{~kg} / \mathrm{ha})$ was less than the observed sorghum yield (Table 4$)$. Values of standard deviation for simulated sorghum grain yield were higher in respect to observed yield. It further showed that sorghum grain yield was perfectly evaluated as it was indicated by the lower value of RMSE (0.15). Ninety-nine percent of the total variation was explained by the model $\left(R^{2}=0.99\right)$. Values of the modelling efficiency index $(E F=0.99)$ and of the index of agreement $(\mathrm{d}$-index $=0.98)$ confirmed the good concordance between observed and estimated values by the CSM-CERES-Sorghum model (Table 4).

The evaluation process revealed that the model predicted sorghum anthesis date, maturity date and sorghum yield very well as the RMSE for all variables were very low (Table 4). This implies that the model was successfully evaluated for the four treatments in question. This is supported by various authors $[6,14,17,18]$.

Table 4 Statistical indexes for the evaluation of CSM-CERES-Sorghum

\begin{tabular}{|c|c|c|c|c|c|c|c|c|}
\hline \multirow[t]{2}{*}{ Evaluation } & & & \multicolumn{2}{|c|}{ Yield (kg/ha) } & \multicolumn{2}{|c|}{ Anthesis (DAP) } & \multicolumn{2}{|c|}{ Maturity (MDAP) } \\
\hline & & & OBS & SIM & OBS & SIM & OBS & SIM \\
\hline Mean & M & & 1143 & 1137 & 54 & 56 & 132 & 132 \\
\hline Standard Deviation & SD & & 155 & 158 & 0 & 0 & 0 & 0 \\
\hline Maximum & MAX & & 1313 & 1311 & 54 & 56 & 132 & 132 \\
\hline Minimum & MIN & & 893 & 881 & 54 & 56 & 132 & 132 \\
\hline Number of samples & $\mathrm{N}$ & & 16 & 16 & 16 & 16 & 16 & 16 \\
\hline Root Mean Square Error & RMSE & & & & & & & \\
\hline Mean Error & $\mathrm{E}$ & & & & & & & \\
\hline Modelling Efficiency & & $\mathrm{EF}$ & & & c & & & \\
\hline Index of agreement & $\mathrm{d}$ & & & & c & & & \\
\hline Coefficient of determination & $\mathrm{R}^{2}$ & & & & & & & \\
\hline
\end{tabular}

Anthesis: (DAP=day to flowering after planting) and maturity (MDAP =days to maturity after Planting ns: not significant

\subsection{Simulated yields versus observed yields}

Grain yields obtained by the model were closer to mean yields obtained in the four treatments within the three experimental years (Figure 4). In 2015, simulated sorghum grain yield was the same as for observed yield. In 2016, simulated sorghum yield was higher than observed yields for all treatments except NT. The results in 2017 growing season showed that the simulated sorghum grain yield was the same as the observed yield for all treatments (Figure 4). The model thus simulated the grain yield well for all treatments (Figure 4). These comparisons demonstrate that the model has the potential to simulate sorghum yield. 


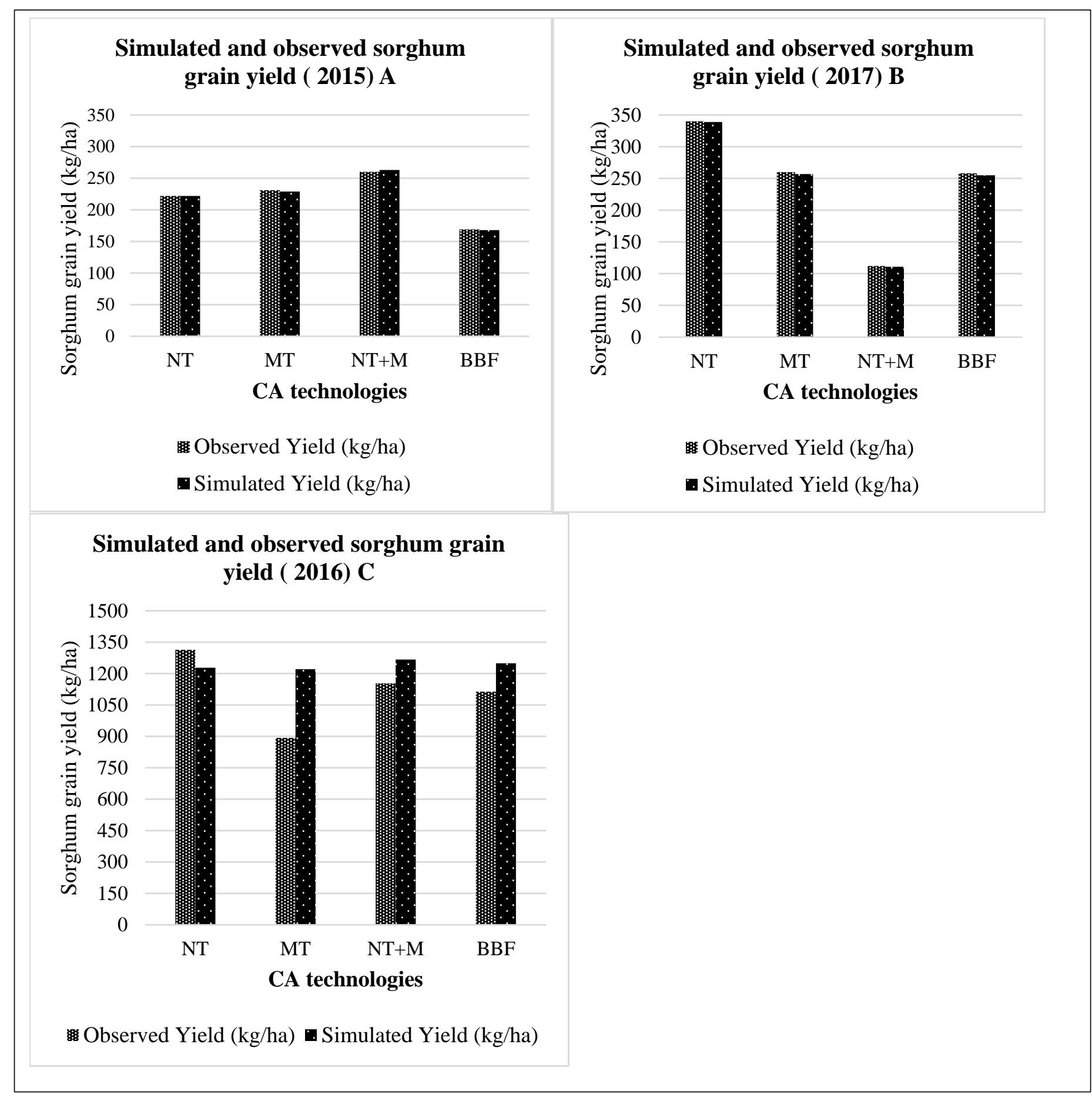

Figure 4 Evaluation of sorghum grain yield for CA technologies under continuous sorghum

\subsection{Prediction of sorghum grain yield under CA using mid-century weather data (2040 -2070)}

\subsubsection{Climate change projections in mid - century (2040-2070)}

The monthly average values of the forecasted weather data used for the simulations of sorghum yield in the mid-century are given in Figure 5. According to the forecasted weather data both the maximum and minimum air temperatures in Pandamatenga will be increased beyond the present conditions in RCP 4.5 and RCP 8.5 climate scenarios. An increased amount of rainfall will be experienced in the RCP 4.5 climate scenario (hot and dry and hot and wet) in the months of January, October, November and December while in February, March and April the amount of rainfall will be decreased. Also, in the RCP 8.5 climate scenario the amount of rainfall will be decreased in the mid - century. Temperature and 
rainfall are the main critical factors that affect the growth and yield of sorghum. Therefore, these changes will be attributed to the yields of sorghum in the Pandamatenga area.

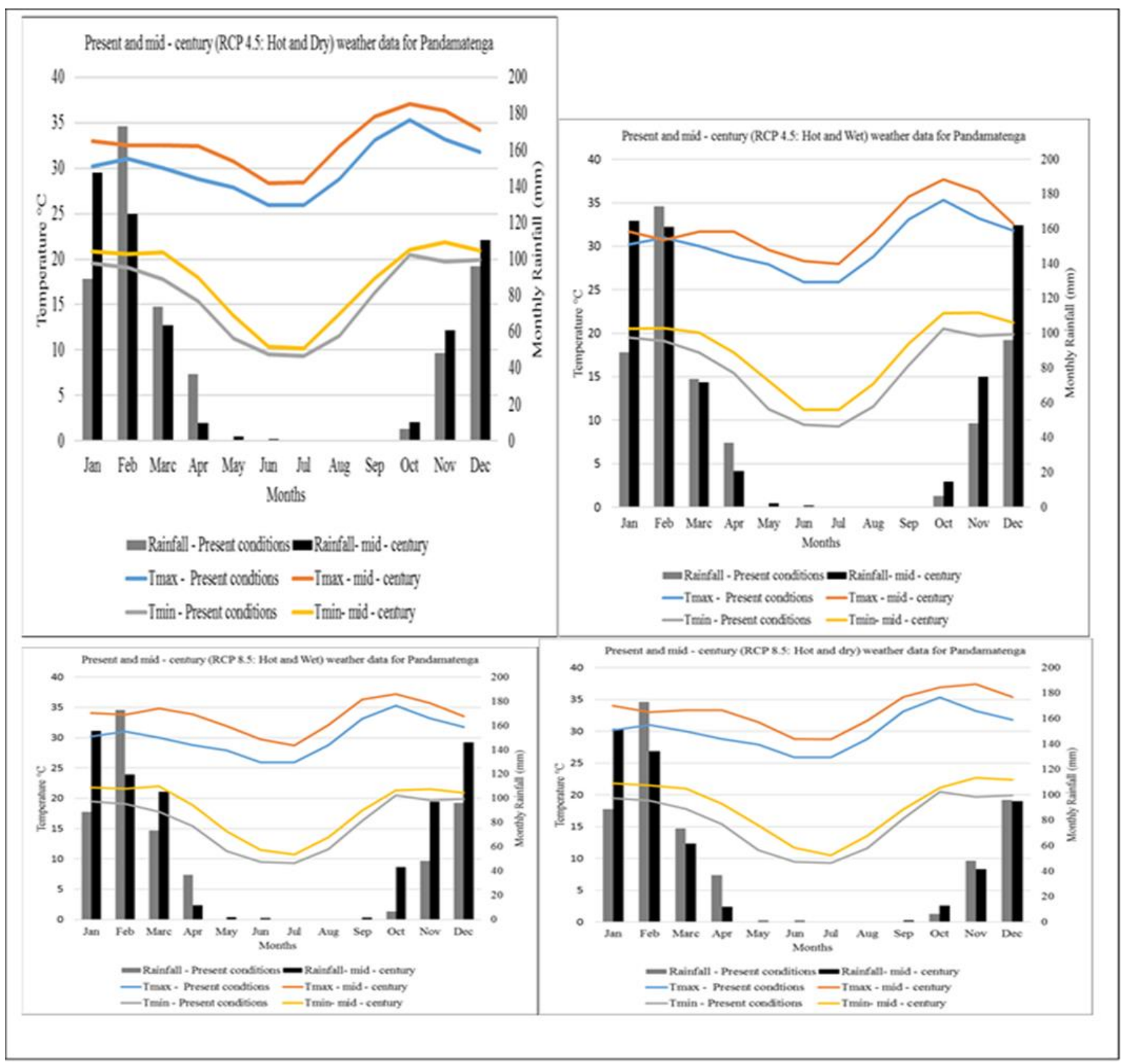

Figure 5 Present and mid - century weather data for Pandamatenga Agricultural Research Station

\subsubsection{Predicted sorghum grain yield under CA in the mid-century}

Simulation results of sorghum growth and yield under future climate conditions in DSSAT model are presented in Table 5 and Figure 6. According to these results, under climate change scenario (RCP 4.5 and 8.5) sorghum yield will be decreased in the mid-century as compared to 2016 conditions. In the mid- century, the growth periods will also be reduced as compared to 2016 conditions (Table 5). This can be attributed to the high temperatures which will be experienced in the mid-century. High temperatures increase the development rate of sorghum hence shortening the time to flowering which leads to yield reduction as demonstrated by Fu et al [19]. As rainfall will be decreased in the growing season months (Figure 5), water stress problems are likely to exacerbate plant cell dehydration ultimately resulting in yield reduction. 
Table 5 Predicted sorghum grain yield (kg/ha) using the mid - century weather data (2040 -2070).

\begin{tabular}{|ll|l|l|l|l|}
\hline Present condition & & Mid - century & & \\
\hline 2016 & RCP 4.5 & & RCP 8.5 & \\
\hline & & Hot and dry & Hot and wet & Hot and dry & Hot and wet \\
\hline NT $\quad 1228$ & 869 & 896 & 858 & 1090 \\
\hline MT $\quad 1221$ & 866 & 886 & 856 & 1084 \\
\hline NT+M $\quad 1267$ & 878 & 912 & 868 & 1146 \\
\hline BBF $\quad 1249$ & 874 & 904 & 862 & 1098 \\
\hline DAP $\quad 56$ & 54 & 56 & 51 & 50 \\
\hline MDAP & 132 & 96 & 99 & 92 & 89 \\
\hline \multicolumn{7}{|l|}{ Anthesis: (DAP=day to flowering after planting) and (MDAP =days to maturity after planting }
\end{tabular}

Identifying the most effective CA technologies is the first step towards preparing smallholder rainfed farmers to face climate change. Selecting the most appropriate system for a soil and cropping situation requires matching the operations to the crop sequence, topography, soil type and weather conditions. In this study, it has been shown that $\mathrm{NT}+\mathrm{M}$ will have the highest sorghum grain yield in the Vertisols of Pandamatenga during the mid - century both under RCP 4.5 and 8.5 (Table 5). The highest yield under this practice is attributed to the fact that no tillage improves soil fertility as there is less soil disturbance and this allows soil organic matter retention. Mulch also improves soil moisture conditions by reducing evaporation and runoff, thus benefiting crop growth under dry conditions which will be experienced in the mid - century. Similar tillage and mulching benefits on sorghum grain yield have been reported [20]. Broad Bed and Furrow had the second highest sorghum yield from the field experiments at Pandamatenga as well as in the mid - century under climate change scenarios of RCP 4.5 and 8.5. This BBF system is an efficient soil and water conservation strategy by reducing runoff and draining excess water from the beds as Vertisols are prone to waterlogging.
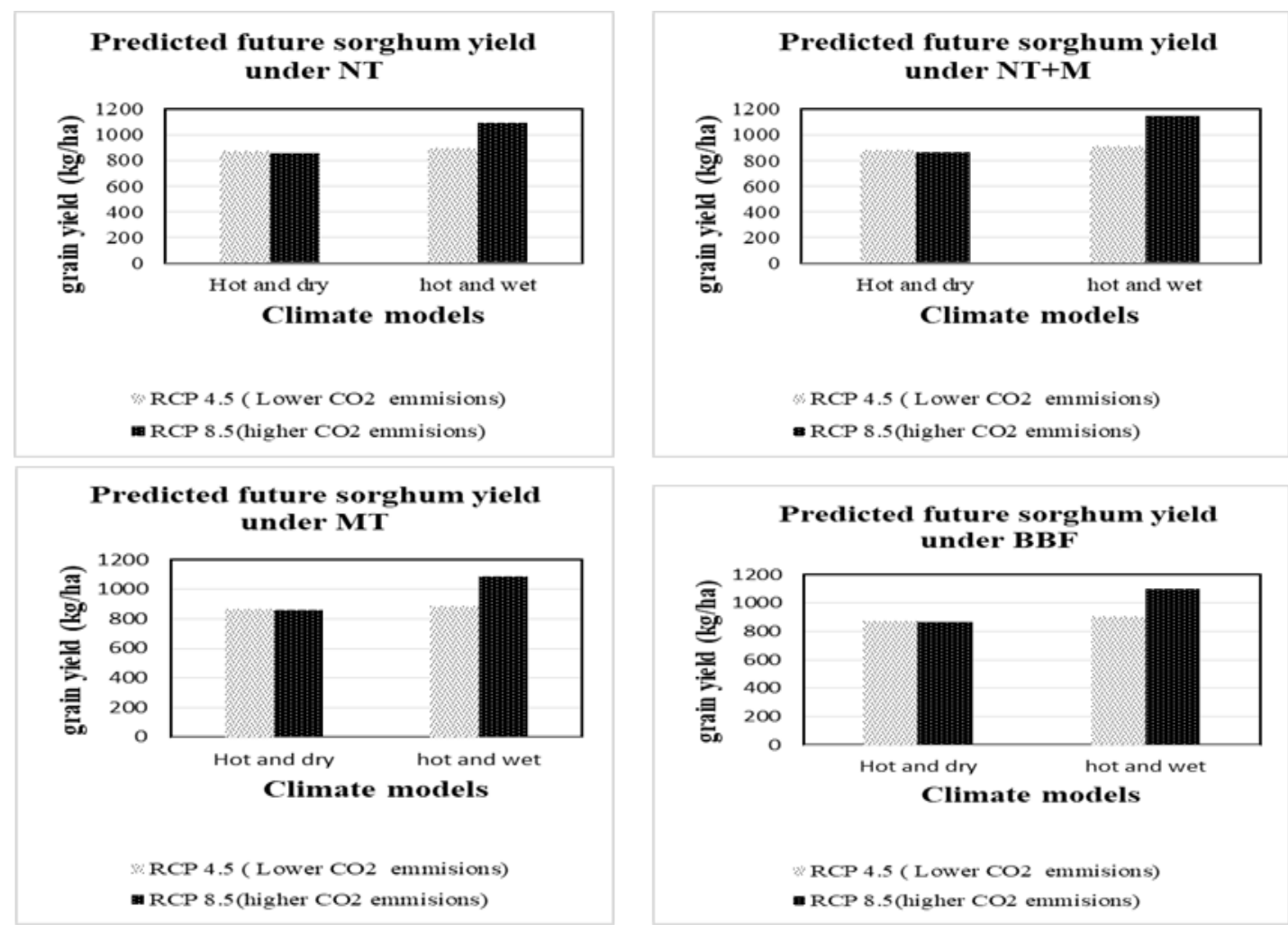

Figure 6 Predicted future sorghum grain yield (kg/ha) under CA technologies. 


\section{Conclusion}

The DSSAT crop model provided reasonable predictions of sorghum grain yield under NT, MT, NT+M and BBF on Vertisols of Pandamatenga. It can therefore be a useful tool in assisting agricultural decision makers to identify efficient cropping systems for increasing crop yields and decreasing environmental impact in Pandamatenga vertisols. The model predicted that sorghum grain yield will be decreased in the mid - century. The model, furthermore, predicted that smallholder rainfed sorghum grain yield will be increased if $\mathrm{NT}+\mathrm{M}$ is practiced. It is recommended that the DSSAT model be integrated into agricultural policy planning to assist smallholder rainfed farmers on improving crop production for sustainable food security.

\section{Compliance with ethical standards}

\section{Acknowledgments}

The authors are deeply grateful to the Centre for Coordination of Agricultural Research and Development for Southern Africa (CCARDESA) which funded this research Furthermore, sincere thanks go to Prof. F. Pule - Meulenberg who coordinated the Mogae F.G scholarship that helped them financially to complete the study. The support and cooperation of Pandamatenga personnel from the Departments of Crop Production and Agricultural Research of the Ministry of Agriculture Development and Food Security, who provided relevant secondary data and facilitated field work, is highly appreciated.

\section{Disclosure of conflict of interest}

We the authors of this paper hereby declare that there are no competing interests in this publication.

\section{References}

[1] Araya T, Nyssen J, Govaerts B, Deckers J, Sommer R, Bauer H, Gebrehiwot K, Cornelis WM. Seven years resourceconserving agriculture effect on soil quality and crop productivity in the Ethiopian drylands. Soil and Tillage Research. 2016; 163: 99-109.

[2] Hati KM, Chaudhary RS, Mandal KG, Bandyopadhyay KK, Singh RK, Sinha NK, Mohanty M, Somasundaram J, Saha R. Effects of tillage, residue and fertilizer nitrogen on crop yields, and soil physical properties under soybean wheat rotation in Vertisols of Central India. Agricultural Research. 2015; 4(1): 48-56.

[3] Oicha T, Cornelis W, Verplancke H, Nyssen J, Deckers J, Behailu M, Haile M, Govaerts B. Short-term effects of conservation agriculture on Vertisols under tef (Eragrostis tef Zucc. Trotter) in the nothern Ethopian highlands. Soil and Tillage Research. 2010; 106(2): 294-302.

[4] Wall PC, Thierfelder C. The Role and Importance of Residues: BMZ and IFAD- funded projects on Facilitating the Adoption of Conservation Agriculture in Eastern and Southern Africa. CIMMYT Technical Bulletin, Harare, Zimbabwe. 2017; 2.

[5] Mohanty M, Sinha NK, Hati KM, Painuli DK, Chaudhary RS. Stability of soil aggregates under different vegetation covers in a Vertisol of Central India. Journal of Agricultural Physics. 2012; 12(2): 133-142.

[6] Ngwira AR, Aune JB, Thierfelder C. Soil \& Tillage Research DSSAT modelling of conservation agriculture maize response to climate change in Malawi. Soil and Tillage Research. 2014; 143: 85-94.

[7] Jones JW, Hoogenboom G, Porter CH, Boote KJ, Batchelor WD, Hunt LA, Wilken PW, Singh U, Gijsman AJ, Ritchie JT. (2003). The DSSAT cropping system model. European Journal of Agronomy. 2003; 18: 235-265.

[8] Soldevilla-Martinez M, Martin- Lammerding D, Tenorio JL, Walter I, Quemada M, Lizaso JI. Simulating improved combinations tillage-rotation under dryland conditions. Spanish Journal of Agricultural Research. 2013; 11(3): 820-832.

[9] Msongaleli B, Rwehumbiza F, Tumbo SD, Kihupi N. Sorghum yield response to changing climatic conditions in semiarid Central Tanzania: Evaluating Crop Simulation Model applicability. Agricultural Sciences. 2014; 5: 822833.

[10] Tapela M, Kayombo B, Pule - Meulenberg F. Potential for No-Tillage agriculture in the Pandamatenga Vertisols of Botswana. Agricultural Mechanization in Asia, Africa and Latin America. 2017; 38(2): 42-47. 
[11] Centre for Applied Research ( CAR). Environmental and Social Impact Assessment of the Zambezi Integrated Agro-Commercial Development Project (vls 1-3). Ministry of Agriculture, Government of Botswana, Gaborone. 2010.

[12] Willmott CJ, Ackleson SG, Davis RE, Feddema JJ, Klink KM, Legates DR, O' donnel J, Rowe CM. Statistics for the evaluation and comparison of models. Journal of Geophysical Research. 1985; 90(20): 8995-9005.

[13] Yang JM, Yang JY, Liu S, Hoogenboom G. An evaluation of the statistical methods for testing the performance of crop models with observed data. Agricultural Systems. 2014; 127: 81-89.

[14] Liu S, Yang JY, Zhang XY, Drury CF, Reynolds WD, Hoogenboom G. Modelling crop yield, soil water content and soil temperature for a soybean-maize rotation under conventional and conservation tillage systems in Northeast China. Agricultural Water Management. 2013; 123: 32-44.

[15] Crespo 0. Methodology of developing the future weather climate from Agricultural Model Intercomparison and Improvement Project (AgMIP). Research Project Paper. University of Cape Town. 2015.

[16] Stocker T. (Ed). Climate Change 2013 - The physical science basis: Working Group I contribution to the Fifth assessment report of the Intergovernmental Panel on Climate Change. Cambridge University Press. 2014.

[17] Carboni G. Evaluation of conservation tillage and rotation with legumes as adaptation and mitigation strategies of climate change on durum wheat in Sardinia. 2010.

[18] Harb OM, Abd El-hay GH, Hager MA, Abou El-enin MM. Calibration and validation of DSSAT V.4.6.1, CERES and CROPGRO-Models for simulating No-Tillage in Central Delta, Egypt. Agrotechnol. 2016; 5: 143.

[19] Fu T, Ko J, Wall GW, Pinter PJ, Kimball BA, Ottman MJ, Kim H. Simulation of climate change impacts on grain sorghum production grown under free air $\mathrm{CO}_{2}$ enrichment. International Agrophysics. 2016; 30: 311-322.

[20] Mehmood S, Zamir S, Rasool T, Akbar W. Effect of tillage and mulching on soil fertility and grain yield of sorghum. Scientia Agriculturae. 2014; 4(1): 31-36. 